\title{
Influence of Forms of Thinking Styles on Emotional Intelligence of Teacher Educators
}

\author{
${ }^{1}$ Dr. Sumanlata Saxena, ${ }^{2}$ Dr. Siddharth Jain, ${ }^{3}$ Dr. Rajat Jain \\ ${ }^{I}$ Professor, kalyan pg college, bhilai (c.g.), India \\ ${ }^{2}$ Reader, D.P. Vipra College Of Education, Bilaspur (C.G.), India \\ ${ }^{3}$ Asst. Prof., Shri Shankaracharya Mahavidyalya, Bhilai (C.G.), India
}

\begin{abstract}
Thinking differently is a unique characteristic of a man, this fact was realized by R.J. STERNBERG (1988). He emphasized that thinking styles are preferred way of thinking. He classified 13 different thinking styles based on functions, forms, level, scope and leaning. On the other hand Emotional intelligence is a ability to sense, understand and effectively apply emotions for better inter personal relations (COOPER AND SAWAF, 1997). GOLEMAN (1995) characterized Emotional Intelligence as the ability of self awareness, mood management, self motivation, empathy and managing relationships. No doubt Thinking Style and Emotional Intelligence both are cognitive abilities of an individual. In this study an attempt has been to find the relationship of these two cognitive abilities.

The objective of the study was to find out influence of various forms (monarchic, hierarchic, oligarchic and anarchic) of Thinking Styles on Emotional intelligence of teacher educators of teacher training colleges of Chhattisgarh state. The sample comprises of 25 male and 25 female teacher educators. They were administered part of 'Thinking Style Scale' (only FORMS of thinking style) developed by JOHN, SINGH AND VERMA (2006) and 'Emotional Intelligence Scale' developed by HYDE AND PATHE (2002).

The obtained data was analyzed by calculating $M, S D$ and 't' value to test the significance of the hypotheses of the study. The results indicates that all the four FORMS of thinking styles have shown significant difference on emotional intelligence. Apart from this gender difference of teacher educators has also shown significant difference on emotional intelligence.
\end{abstract}

\section{Introducation :-}

The idea of styles of cognition was initially introduced by Allport (1937). The concept of thinking style is a relatively recent field for the researchers. Thinking style is major component of cognitive style. Thinking styles is based on the work done by R.J. Sternberg (1994) on 'mental self government'. Central to this theory is the notion that people manage their everyday activity, and their work field responsibilities by using thirteen (13) different thinking styles in a way that feel comfortable in it.

Tables 13 thinking styles under 5 sections (Sternberg)

\begin{tabular}{|c|c|}
\hline \multicolumn{2}{|c|}{ The Five Sections (subscales) are:- } \\
\hline 1. Legislative & - Creative derringer without armature \\
\hline 2. Executive & - Implement with full support \\
\hline 3. Judicial & - Judging comparing \& evaluating \\
\hline \multicolumn{2}{|l|}{ B - Forms - } \\
\hline 1. Monarchic & -Focused on one goal limited \\
\hline 2. Hierarchic & - Systematic approach for multiple goals \\
\hline 3. Oligarchic & - Multiple goals but priority not clear confused \\
\hline 4. Anarchic & - Follows no rule, Random, Freedom \\
\hline \multicolumn{2}{|l|}{ C-Levels - } \\
\hline 1. Global & - Prefers to deal with large $\&$ global issue, abstraction \\
\hline 2. Local & -Specific, Local, Concrete \\
\hline \multicolumn{2}{|l|}{ D-Scope - } \\
\hline 1. Intemal & - Focused inward. Torte oriented \\
\hline 2. External & - Out going, people oriented \\
\hline \multicolumn{2}{|l|}{ E - Leanings - } \\
\hline 1. Liberal & - Out of rule, new way \\
\hline 2. Conservativ & - Conventional \\
\hline
\end{tabular}


After Sternberg's initial work on 'mental self government' lot of attempts have been made on issue. Zhang lifung (1990, 2001), Zhang \& Sternberg (2001) have studied thinking styles of students in and its impact on their academic performance. Luyben (2003) studies thinking styles of the of the teachers. Zhang (200) Studies thinking styles in developing the leaders of tomorrow.

In India Verma \& Sharma (2003) studies thinking styles of would be teachers. Verma \& sood (2006) Studies the correlation of thinking style and creativity of teachers.

The second important variable of the study is Emotional Intelligence. For a long period it is believed that IQ is the main determinant of a person's behavior in his sorio - cognitive environment, bout now psychologists believe that emotions are the most powerful regulating force of human energy. Goleman (1995) characterised emotional intelligence as ability of self awareness, mood management, self motivation, empathy and managing inter-personal relationships. Cooper and Sawag (1997) characterised emotional intelligence as an ability to sense, understand and effective application of emotions for better interpersonal relations.

The EQ (Emotional Quotient) is more appropriate predictor of on individual ability to behave properly in interpersonal (situation, Berton, Dialman and cattell (1972), Finnegan (1998) Cangelosi \& Peterson (1998), Pool (1997), Rhode Island (1997) Cooper \& Murphy (2000) have studies emotional intelligence in relation to various Psychological \& demographic variables, In India subapathe (1986), D. Prasad (2002) V.Khera \& Sarabjeet (1999), Kaur (2001), Miglani (2001), Lekhi (2005), Paramjeet and Gurminder (2005) have done some remarkable work in this field.

Considering the importance of these two variables i.e. thinking styles and emotional intelligence this study have been taken up to see the influence of forms of thinking styles on emotional intelligence of the teacher educators.

\section{Objectives :-}

1. To find out the influence of various forms of thinking on emotional intelligence of teacher educators of teachers training college of Chattisgarh state.

2. To see the effect of sex difference on emotional intelligence.

\section{Delimitations: -}

The study was delimited to the teacher's education of B.Ed. \& M.Ed. teacher training college of Bilaspur and Raipur of Chhattisgarh state.

The sample -The universe of the study was training institutions and the teacher educator teaching in these institutions.

There are approximate 100 institutions. For the present study the selected universe was the teacher training college coming under Raipur and Bilaspur city of Chhattisgarh state. The study was conducted on 10 colleges.

Stratified random sampling was adopted to select 25 male $\& 25$ female in total 50 teacher educators.

Sample - The sample distribution is shown below in table -2

Table N0. 2 Sample Distribution

\begin{tabular}{|c|c|c|c|}
\hline & Male & Female & Total \\
\hline $\begin{array}{c}\text { Teacher } \\
\text { Educators }\end{array}$ & 25 & 25 & 50 \\
\hline
\end{tabular}

Tools: - In this study thinking style scale (Only From) developed by John singh \& Verma (2006) and Emotional Intelligence scale developed by Hyde and pathe (2002) were used to measure respective abilities of the teacher educators. Both the tools are recently developed reliable and valid tools.

\section{Hypotheses of the study:-}

In the present study following hypotheses were formed:-

$\mathbf{H}_{1}$ - There shell be significant difference in emotional Intelligence of monarchic and hierarchic teacher educators.

$\mathbf{H}_{2}$ - There shell be significant difference monarchic and oligarchic teacher educators on account of their emotional intelligence.

$\mathbf{H}_{3}$ - There shell be significant difference in monarchic and anarchic of their emotional intelligence.

$\mathbf{H}_{4}$ - There shell be significant difference in Emotional Intelligence of hierarchic and oligarchic teacher educators.

$\mathbf{H}_{5}$ - There shell be significant difference between hierarchic and anarchic on their emotional intelligence. 
$\mathbf{H}_{\mathbf{6}}$ - There shell be significant difference between emotional intelligence of oligarchic and anarchic teacher educators.

$\mathbf{H}_{7}$ - Male and Female teachers difference significantly in their emotional intelligence.

\section{RESULTS AND DISCUSSIONS -}

In this study by applying thinking styles scale (Forms) teacher educators were identified who sorrel high on various forms of thinking styles. Out of 50 teacher educators 14 were high on monarchic style, 8 were high on hierarchic , 18 on oligarchic and 10 on anarchic.

TABLE - 3 NO. OF TEACHER EDUCATOR IN DIFFERENT FERMS OF THINKING STYLE

\begin{tabular}{|l|l|l|l|l|l|}
\hline & $\begin{array}{l}\text { M } \\
\text { (Monarchic } \\
\text { Style) }\end{array}$ & $\begin{array}{c}\text { H } \\
\text { (Hierarchic } \\
\text { Style) }\end{array}$ & $\begin{array}{l}\text { O } \\
\text { (Oligarchic } \\
\text { Style) }\end{array}$ & $\begin{array}{c}\text { A } \\
\text { (Anarchic) }\end{array}$ & Total \\
\hline $\begin{array}{l}\text { Teacher } \\
\text { Educators }\end{array}$ & 14 & 08 & 18 & 10 & 50 \\
\hline
\end{tabular}

\section{VERIFICATION OF HYPOTHESES:-}

TABLE - 4 ' $t$ ' VALUES \& SIGNIFICANCE FOR HYPOTHESES

\begin{tabular}{|c|c|c|c|c|c|c|}
\hline Hypotheses & $\begin{array}{c}\mathrm{t} \\
\text { (between) } \\
\text { Thinking } \\
\text { styles } \\
\end{array}$ & $\begin{array}{l}\text { Mean(emotional } \\
\text { Int. Score) }\end{array}$ & $\mathrm{SD}$ & df & t Value & Significance \\
\hline $\mathrm{H}_{\mathrm{l}}$ & $\mathrm{t}(\mathrm{M} \& \mathrm{H})$ & $\begin{array}{l}\text { Mm- } 67.2 \\
\text { MH- } 72.6\end{array}$ & $\begin{array}{l}8.9 \\
7.92\end{array}$ & $\begin{array}{ll}14 & \\
8 & 20\end{array}$ & 1.89 & Insignificant \\
\hline $\mathrm{H}_{2}$ & $\mathrm{t}(\mathrm{M} \& 0)$ & $\begin{array}{l}\text { Mm-97.2 } \\
\text { MO-50.4 }\end{array}$ & $\begin{array}{l}8.9 \\
12.6\end{array}$ & $\begin{array}{ll}14 & \\
18 & \\
\end{array}$ & 3.89 & .01 , Significant \\
\hline $\mathrm{H}_{3}$ & $t(M \& A)$ & $\begin{array}{l}\text { Mm-67.2 } \\
\text { MA-58.8 }\end{array}$ & $\begin{array}{l}8.9 \\
11.72\end{array}$ & ${ }_{10}^{14} 22$ & 2.71 & .01 , Significant \\
\hline $\mathrm{H}_{4}$ & $t(\mathrm{H} \& O)$ & $\begin{array}{l}\text { MH-72.6 } \\
\text { MO-50.4 }\end{array}$ & $\begin{array}{l}7.92 \\
12.6\end{array}$ & $\begin{array}{ll}8 & \\
18 & \\
\end{array}$ & 8.11 & .01 , Significant \\
\hline $\mathrm{H}_{5}$ & $t(H \& A)$ & $\begin{array}{l}\text { MH-72.6 } \\
\text { MA-58.8 }\end{array}$ & $\begin{array}{l}7.92 \\
11.72\end{array}$ & $\begin{array}{ll}8 & \\
10 & 16\end{array}$ & 6.58 & .01 , Significant \\
\hline $\mathrm{H}_{6}$ & $t(0 \& A)$ & $\begin{array}{l}\text { MO-50.4 } \\
\text { MA-58.8 }\end{array}$ & $\begin{array}{l}12.6 \\
11.72\end{array}$ & $18 \quad 26$ & 2.01 & Insignificant \\
\hline \multicolumn{7}{|c|}{ Sex difference } \\
\hline $\mathrm{H}_{7}$ & $\mathrm{t}(\mathrm{M} \& \mathrm{~F})$ & \begin{tabular}{|l} 
M Male -67.15 \\
MFemale- \\
62.81
\end{tabular} & $\begin{array}{l}11.15 \\
14.12\end{array}$ & $\begin{array}{ll}25 & \\
25 & 48\end{array}$ & 1.15 & Insignificant \\
\hline
\end{tabular}

Table - 5 Expected Values 


\begin{tabular}{|c|c|c|c|c|c|c|c|}
\hline \multirow{2}{*}{$\begin{array}{l}\text { Level of } \\
\text { Significance }\end{array}$} & \multicolumn{10}{|c|}{ Df } \\
\cline { 2 - 9 } & $\mathbf{1 6}$ & $\mathbf{2 0}$ & $\mathbf{2 2}$ & $\mathbf{2 4}$ & $\mathbf{2 6}$ & $\mathbf{3 2}$ & $\mathbf{4 8}$ \\
\hline .05 & 2.12 & 2.09 & 2.07 & 2.06 & 2.06 & 2.02 & 2.01 \\
\hline .01 & 2.92 & 2.84 & 2.82 & 2.80 & 2.78 & 2.71 & 2.68 \\
\hline
\end{tabular}

\section{Results:}

From table No.4 the following results are obtained:-

The value insignificant between monarchic and hierarchic thus $\mathrm{H}_{1}$ rejected.

1. Monarchic are found to significantly more emotionally intelligent than anarchic teacher education thus $\mathrm{H}_{2}$ retained.

2. Monarchic teacher educators are found significantly higher on emotional intelligence than anarchic teacher educators thus $\mathrm{H}_{3}$ retained.

3. Hierarchic teacher educators are significantly higher than oligarchic on their emotional intelligence thus $\mathrm{H}_{4}$ retained.

4. Hierarchic have shown significantly more emotional intelligence than anarchic teacher educators thus $\mathrm{H}_{5}$ is also retained.

5. Oligarchic teacher educators have shown insignificantly low emotional intelligence than anarchic teacher educators thus $\mathrm{H}_{6}$ rejected.

These results indicate that while comparing emotional intelligence on account of various thinking styles four comparisons have shown significant difference which leads towards comfortable generalization that

(a) thinking style has a clear influence on emotional intelligence of teacher educators and

(b) Monarchic and hierarchic teacher educators are found emotionally more intelligent than teacher educators having oligarchic and anarchic thinking styles.

6. Gender difference has shown no significant effect on emotional intelligence thus $\mathrm{H}_{7}$ is rejected.

In this study thinking style of teacher educators is a clear indicator of their emotional intelligence. There is vast opportunity to study thinking styles of teachers and teacher educators in relation to various other variables like - creativity, emotional maturity, teaching competency, teachers role commitment, teacher effectiveness and so on.

\section{Bibliography}

[1]. Bernet, M. - (1996), Emotional Intelligence: Components and Correlate. Toronto, Canada: American Psychological Association

[2]. Bhargava, M.; Mathur, M. (2005), Psychometerics and statistical applications in Educational and behavioural Science. Bhargava Books House, Agra.

[3]. Boler, M. - Feeling Power : Emotions and Educations, London : Routledge, 1999

[4]. Bradberry, Travis and Greaves, Jean, The Emotional Intelligence Quickbook. New York: Simon and Schuster. (2005)

[5]. Chaster, W.H. (1960), Encyclopedia of educational research, Third Ed.

[6]. Cooper, R.K. and Sawaf, A. - Executive EQ Emotional Intelligence in leadership and Organization. New York : Perigee Book, 1994.

[7]. Faure, E. et al. (1973). Learning to be (UNESCO), Sterling Publishers Pvt. Ltd., New Delhi.

[8]. Guilfored, J.P. (1950), Fundamental Statistics in Psychology and Education, Second Edition, Mc-Graw Hill Book Corn, Inc. N.Y.

[9]. Muirhead, B. (2007), Literature reviews : Advising doctoral students, Managers journal of Educational Technology, 3(4), Jan to March, P. 12-47.

[10]. Sharma, R.A. (1980), Technology of Teaching, Loyal Book Depot., Meerut.

[11]. Verma, B.P. \& Sood, Monika (2006), Creativity gender and thinking styles, Psycholingua, 36(1), Jan. 06, P. 3.

[12]. Verma, Saroj \& Sharma, K.P. (2003), Thinking styles of many prospective secondary teachers, 33(2), July 2002, Psycholingua, P. 1.

[13]. Verma, Saroj (2006), Sex difference in thinking style of teachers trainees, IJPE, 37 (2), July 2006, P. 127.

[14]. http://www.aare.edu.au/02pap/abs02.htm\#02522

[15]. http://www.eric.ed.gov/

[16]. http://hum.sayepubcom/Cgi

[17]. http://www.stevepavlinna.comldlog/2007/l 1.

[18]. http://www.vadamsbooks.com/education.htm 